\title{
Research Paper \\ Predictors the quality of life and psychological well-being of mothers of students with intellectual disability mediated by the mother's perceived social support
}

\section{Tayebe Taziki ${ }^{1}$, Khoda Morad Momeni ${ }^{2}$, Jahangir Karami ${ }^{2}$, Gholamali Afroz ${ }^{3}$}

1. Ph.D Student in Psychology, Department of Psychology, Faculty of Social Sciences, Razi University, Kermanshah, Iran. 2. Associate Professor, Department of Psychology, Faculty of Social Sciences, Razi University, Kermanshah, Iran.

3. Professor, Department of Psychology, Faculty of Psychology and Educational Sciences, Tehran University, Tehran, Iran.

Citation: Taziki T, Momeni Kh.M, Karami J, Afroz Gh. Predictors the quality of life and psychological well-being of mothers of students with intellectual disability mediated by the mother's perceived social support. J of Psychological Science. 2021; 20(104): 1345-1361.

URL: https://psychologicalscience.ir/article-1-1187-fa.html
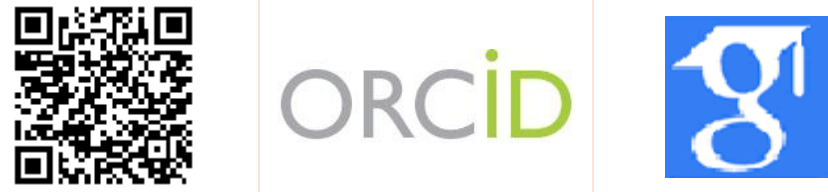

$\underline{10.52547 / J P S .20 .104 .1345}$

\section{A R T I C L E I N F O A B S T R A C T}

\section{Keywords:}

Psychological well-

being,

Perceived Social

Support,

Quality of life,

Mothers of students with

intellectual disability

Received: 17 Mar 2021

Accepted: 10 Apr 2021

Available: 23 Oct 2021
Background: Many studies have been conducted on behavioral problems and social skills with quality of life and psychological well-being, but there is a research gap on the above variables as predictors of quality of life and psychological well-being mediated by perceived social support.

Aims: The aim of this study was to investigate the predictors of quality of life and psychological well-being of mothers of students with intellectual disability mediated by the mother's Perceived Social Support.

Methods: In this descriptive-correlational study, 298 students (out of 878 students) from primary schools with students with intellectual disability in Golestan province, in the academic year 13981399, were selected by multi-stage cluster sampling. The instruments used in the study were: The Children,s behavior questionnaire (Rutter,1967), Social skills scale (Matson et al, 1983), Multidimensional Scale of Perceived Social Support(Zimet et al, 1988), Quality Of Life (World Health Organization, 1994), and Psychological Wellbeing Scale (Ryff, 1980). Data were analyzed by descriptive statistics, Pearson correlation test and structural equation modeling.

Results: The results showed that social skills and perceived social support positively and significantly and behavioral problems negatively and significantly predict quality of life and psychological well-being. The mediating role of perceived social support in relation to social skills and behavioral problems with quality of life and psychological well-being was also confirmed $(\mathrm{P}<0.01)$.

Conclusion: Based on the research findings, it can be concluded that increasing social skills and reducing students' behavioral problems in school improves the quality of life and psychological wellbeing of their mothers.

* Corresponding Author: Khoda Morad Momeni, Associate Professor, Department of Psychology, Faculty of Social Sciences, Razi University, Kermanshah, Iran.

E-mail: kh.momeni@razi.ac.ir.

Tel: (+98) 9181323767

2476-5740/ (C) 2021 The Authors. This is an open access article under the CC BY-NC-ND license

(https://creativecommons.org/licenses/by-nc/4.0/). 


\section{Extended Abstract}

\section{Introduction}

Intellectual Disability (ID) is a major medical, psychological, and social problem (Kolesnikova et al, 2018) that affects $1-3 \%$ of the population (Simms, 2018; Vega, Hui, Harman, Mildred \& Schroeder, 2018). The high prevalence of intellectual disability makes it necessary to study in this field.

Caring for a child with a mental disability in the family affects the quality of life and psychological well-being of mothers (Lima-Rodriguez, BaenaAriza, Dominguez-Sanchez \& Lima-Serrano, 2018), which is a big issue. Therefore, research on these two variables is important and necessary and it is necessary to examine the factors affecting these variables such as behavioral problems and social skills.

Psychological well-being refers to a life full of purpose, meaning, transformation, and high-quality relationships with others, and includes six key dimensions of mental health: self-acceptance, positive relation with others, autonomy, Environmental mastery, Purpose in life, and personal growth. (Ryff, 2014; Ryff \& Singer, 2008). The concept of quality of life encompasses attention to spirituality and individual feelings and all levels of needs from physiological needs to the need for selfactualization (Tannenbaum, Ahmed \& Mayo, 2007; Winkler et al, 2014).

Behavioral problems are one of the most common psychological problems in childhood and adolescence (Bulotsky-Shearer, Fantuzzo \& McDermott, 2010; Gomez \& Suhaimi, 2013). There is evidence that child behavioral problems as a risk factor have negative effects on the family and especially the mother (Jones, Hastings, Totsika, Keane \& Ruhle, 2014). Social skills are a set of abilities and behaviors that lead to positive social interaction (Gresham \& Elliott, 2008).

Research background on risk factors, especially the relationship between child-related variables such as behavioral problems and social skills of the child with the quality of life and psychological well-being of the mother is limited (Pozo, Sarria \& Brioso, 2014).
Therefore, the research vacuum is quite noticeable and the study in this field is of great importance.

In addition, researchers believe that one of the mediating variables in the relationship between behavioral problems and social skills of the child with quality of life and psychological well-being is perceived social support. (Malinauskas \& Malinauskiene, 2018; Sun, Wang, Wang, Du \& Zhang, 2019). Therefore, it is necessary to discuss this variable.

Experts acknowledge that an individual's assessment of the availability and appropriateness of support to meet needs is called, when needed, and perceived social assistance assistance (Chadwick \& Collins, 2015; Martins, Peterson, Almeida, MesquitaGuimaraes \& Costa, 2014). The model of Langeland $\&$ Wahl (2009) is one of the related models in relation to the mediating role of perceived social support between life pressures and mental health. This model proves that social support improves mental and physical health and quality of life in individuals by playing a mediating role between the stressors of life and the occurrence of physical and mental problems. In this regard, the results of Pozo et al (2014) in a twodimensional model showed that the relationship between behavioral problems and social skills of the child with quality of life and psychological wellbeing of parents is mediated through perceived social support, which is consistent with the model of Langland and Wahl.

According to current studies, no research has been found to examine the above, especially in the mothers of students with intellectual disability. Also, in some research studies, social support perceived as a mediator between different variables has been investigated. For example, a study of 398 male athletes showed that perceived social support partially mediates the relationship between emotional intelligence and psychological well-being (Malinauskas \& Malinauskiene, 2018). However, no study was found to mediate the perceived role of social support in the relationship between children's behavioral problems and social skills with quality of life and psychological well-being of mothers of students with intellectual disability. Therefore, in the current study, researchers decided to investigate the 


\section{Monthly Journal of Psychological Science}

mediating role of perceived social support in relation to behavioral problems and social skills of the child with the quality of life and psychological well-being of the mother.

\section{Method}

The present study is a descriptive-correlational model of structural equation modeling. The statistical population of the present study included all primary school students with mental disabilities living throughout Golestan province and their mothers. A sample of 298 people was selected by multi-stage cluster sampling. The data were then collected using the following tools and then the data were analyzed by descriptive statistics, Pearson correlation test and structural equation modeling.

The Rutter Children's behavior questionnaire (Rutter, 1967): In this study, the parents' form of this questionnaire (18 questions, 5 subscales) was used to assess children's behavioral and emotional problems. The reliability and accuracy of the questionnaire were $0 / 76$ and $0 / 84$, respectively.

Matson's social skills scale (Matson et al, 1983): In this study, its standardized Iranian form (55 questions, 5 subscales) was used to assess Kokan's social skills. The reliability and accuracy of the questionnaire were $0 / 92$ and $0 / 88$, respectively. Multidimensional Scale of Perceived Social Support (MSPSS) (Zimt et al, 1988): This scale (12 items, 3 subscales) was used to assess mothers' perceived social support. The reliability and accuracy of the questionnaire were $0 / 78$ and $0 / 85$, respectively.

World Health Organization Quality Of Life (WHOQOL-BREF) (1994): Short form (26-item form, 4 subscales) This questionnaire was used to assess mothers' quality of life. The reliability and accuracy of the questionnaire were 0/88 and 0/85, respectively.

Ryff Psychological Wellbeing Scale (RPWBS) (1980): This scale (18-item form, 6 subscales) was used to assess mothers' psychological well-being. The reliability and accuracy of the questionnaire were $0 / 78$ and $0 / 76$, respectively.

\section{Results}

The present study sought to determine the relationship between behavioral problems and social
Vol. 20, No. 104, Autumn(November) 2021

skills of the child with quality of life and psychological well-being of mothers of students with intellectual disability through the mediation of perceived social support. The values obtained for the skewness and elongation of the variables indicated that the default of being normal in the research variables was fulfilled. By examining the statistics of variance inflation and tolerance index, the assumption of non-alignment was also confirmed. Pearson correlation matrix also showed a significant relationship between independent variables (social skills and behavioral problems) with each other, with dependent variables (psychological well-being and quality of life), with mediating variable (Perceived Social Support) and also a significant relationship between dependent variables with Each other, and was mediated by the variable and all these relationships were significant at the level of $0 / 01$.

Figure 1 shows the significant paths as continuous and the non-significant paths as discontinuous lines.

The following are the fitting indices of the structural model in Table 1. As the contents of table 1 show, the structural model fit indices indicate the proper fit of the model. Therefore, the structure of the hypothetical research model is approved.

Table 1. Structural model fit indices

\begin{tabular}{|c|c|c|}
\hline Fitness index & $\begin{array}{c}\text { Acceptable } \\
\text { domain }\end{array}$ & amount of \\
\hline$\overline{X^{2}}$ & - & $466 / 818$ \\
\hline $\mathrm{X}^{2}$ ratio to the degree of freedom & less than 3 & $2 / 358$ \\
\hline Adaptive Fitness Index (CFI) & bigger than $0 / 90$ & $0 / 975$ \\
\hline Increasing Fitness Index (IFI) & bigger than $0 / 90$ & $0 / 975$ \\
\hline Tucker-Lewis Index (TLI) & bigger than $0 / 90$ & $0 / 970$ \\
\hline $\begin{array}{l}\text { second root of the approximation } \\
\text { error variance estimation } \\
\text { (RMSEA) }\end{array}$ & less than $0 / 08$ & $0 / 068$ \\
\hline $\begin{array}{c}\text { Second Root of the Mean } \\
\text { Remaining Squares (SRMR) }\end{array}$ & less than $0 / 08$ & $0 / 043$ \\
\hline $\begin{array}{l}\text { Akaike Information Criterion } \\
\text { (AIC) }\end{array}$ & - & $576 / 818$ \\
\hline
\end{tabular}

The results of Tables 2 and 3 show the direct and intermediate effects of research variables and based on it, the direct and indirect effects of research variables can be confirmed or rejected. 


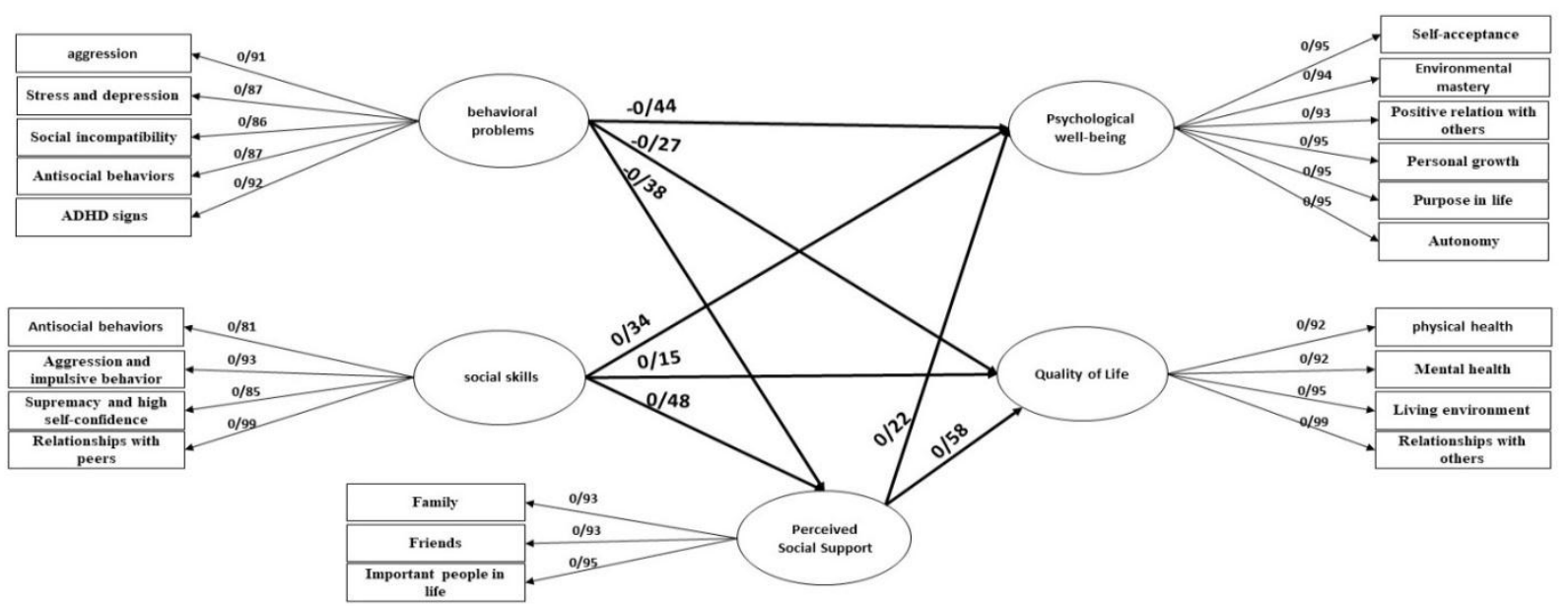

Figure 1. Conceptual model of research with standard path coefficient of research variables in the main model

Table 2. Investigation of direct relationships of variables in the research model

\begin{tabular}{|c|c|c|c|c|c|c|}
\hline independent variable & dependent variable & Standard coefficient & Non-standard coefficient & standard error & $\mathrm{T}$ & $\mathrm{P}$ \\
\hline behavioral problems & Psychological well-being & $-0 / 444$ & $-1 / 162$ & $0 / 137$ & $-8 / 493$ & $0 / 001$ \\
\hline social skills & Psychological well-being & $0 / 337$ & $0 / 263$ & $0 / 039$ & $6 / 671$ & $0 / 001$ \\
\hline social support & Psychological well-being & $0 / 217$ & $0 / 175$ & $0 / 036$ & $4 / 809$ & $0 / 001$ \\
\hline behavioral problems & Quality of Life & $-0 / 269$ & $-1 / 071$ & $0 / 205$ & $-5 / 238$ & $0 / 001$ \\
\hline social skills & Quality of Life & $0 / 146$ & $0 / 173$ & $0 / 060$ & $2 / 884$ & $0 / 004$ \\
\hline social support & Quality of Life & $0 / 578$ & 0/709 & $0 / 060$ & $11 / 856$ & $0 / 001$ \\
\hline behavioral problems & social support & $-0 / 380$ & $-1 / 234$ & $0 / 234$ & $-5 / 274$ & $0 / 001$ \\
\hline social skills & social support & $0 / 482$ & $0 / 466$ & $0 / 068$ & $6 / 831$ & $0 / 001$ \\
\hline
\end{tabular}

As can be seen in Table 5, all variables whose direct paths to the dependent variable have a T value greater than or less than 1.96 or their significance level is less than 0.05 have a significant effect on the dependent variable. Therefore, the direct path of all independent variables in the table with dependent variables is significant.
Table 3 below reports the mediating effect of perceived social support variables on the relationship between children's behavioral problems and social skills with quality of life and maternal psychological well-being, using the bootstrap method with a sampling process 2000 times and with a 95\% confidence interval.

Table 3. Investigation of indirect relationships of variables in the research model

\begin{tabular}{|c|c|c|c|c|c|c|}
\hline independent variable & Mediator & dependent variable & $\mathrm{b}$ & Low limit & upper line & $\mathrm{P}$ \\
\hline behavioral problems & social support & Psychological well-being & $-0 / 216$ & $-0 / 530$ & $-0 / 084$ & $0 / 003$ \\
\hline behavioral problems & social support & Quality of Life & $-0 / 875$ & $-1 / 451$ & $-0 / 382$ & $0 / 011$ \\
\hline social skills & social support & Psychological well-being & $0 / 082$ & $0 / 037$ & $0 / 169$ & $0 / 004$ \\
\hline social skills & social support & Quality of Life & $0 / 331$ & $0 / 208$ & $0 / 527$ & $0 / 008$ \\
\hline
\end{tabular}

According to Table 3 , it can be seen that the indirect effect of the perceived social support variable between both variables of behavioral problems and social skills of children with two variables of quality of life and psychological well-being of the mother is significant.

\section{Conclusion}

Data analysis showed a significant relationship between social skills and behavioral problems with psychological well-being and quality of life. There are several research findings in line with the above results (Jones et al, 2014; Ozgur, Aksu \& Eser, 2018). In addition to the mentioned result, another finding of the present study indicated a significant relationship between perceived social support and psychological 
well-being and quality of life variables. In line with the above findings, many studies have reported a positive and direct relationship between perceived social support and psychological well-being and quality of life (Chen \& Zeng, 2018; Costa et al, 2017). Another finding of this study is that the indirect effect of the perceived social support variable between both variables of behavioral problems and social skills of children with two variables of quality of life and psychological well-being of the mother is significant. And the structural model fit indices indicate the proper fit of the model, so the hypothetical model structure of the research is approved. In line with the above findings, many experts have reported the mediating role of perceived social support between different variables (Malinauskas \& Malinauskiene, 2018; Sun et al, 2019).

In fact, perceived social support acts as a mediator between life stressors (such as the problems of a mentally retarded child) and health variables, and acts as a moderator of life stresses, leading to a reduction in stress, an increase in psychological well-being, and an improvement in quality of life. As a result, it can be said that the two variables of behavioral problems and social skills of children predict the quality of life and psychological well-being of the mother, and in this, the variable of perceived social support plays a mediating role.

\section{Ethical Considerations}

Compliance with ethical guidelines: This article is taken from the doctoral dissertation of the first author in the field of psychology at Razi University of Kermanshah. Participants consciously and voluntarily participated in the research. The principle of confidentiality was observed in the research. The permits related to research in the statistical community were issued by the General Department of Education of Golestan Province.

Funding: This study was conducted as a $\mathrm{PhD}$ thesis with no financial support.

Authors' contribution: The first author was the senior author. The second were the supervisors and the third and forth was the advisors.

Conflict of interest: The authors declare no conflict of interest for this study.

Acknowledgments: I would like to thank the supervisors and consultants of this research, the General Department of Education of Golestan Province, the Department of Exceptional Education of Golestan Province, the esteemed principals of exceptional schools of Golestan Province and mothers with intellectual disability children participating in this study. They helped, thanks and appreciation. 
يبشبينهاى كيفيت زندكى و بهزيستى روانشناختى مادران دانش آموزان كم توان ذهنى با ميانجى كرى حمايت

\section{اجتماعى ادراكشده مادر}

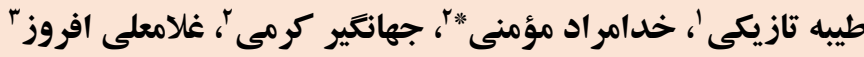

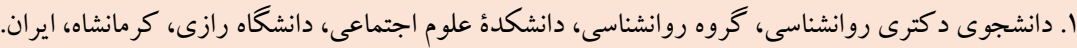

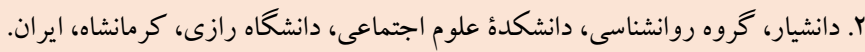

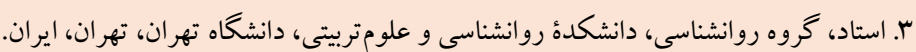

جكيده

زمينه: يُزوهشهاى متعددى بيرامون رابطه مشكلات رفتارى و مهارتهاى اجتماعى با كيفيت زندگى و بهزيستى روانشناختى انجام شده

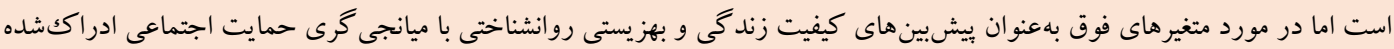
شكاف تحقيقاتى وجود دارد.

هدف: هدف از بثوهش حاضر بررسى بيشين هاى كيفيت زندگى و بهزيستى روانشناختى مادران دانش آموزان كم توان ذهنى با ميانجى كرى حمايت اجتماعى ادراكتشده مادر بود.

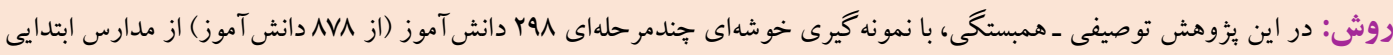

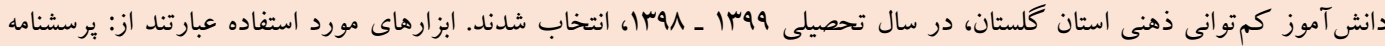

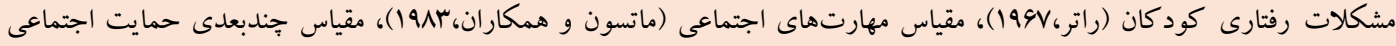

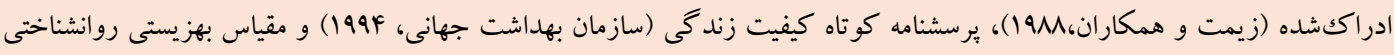

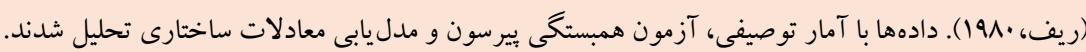
يافته ها: نتايج نشان داد مهارتهاى اجتماعى و حمايت اجتماعى ادراككشده بهطور مثبت و معنادار و مشكلات رفتارى بهطور منفى و معنادار كيفيت زندكى و بهزيستى روانشناختى را ييشينى مى كنند. همجنين نقش ميانجى حمايت اجتماعى ادراككشده در رابطه مهارتهاى

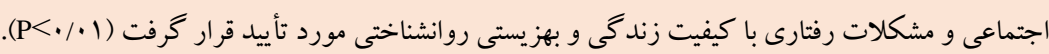
نتيجه كيرى: براساس يافتهاى يزوهش مى توان نتيجه گرفت افزايش مهارتهاى اجتماعى و كاهش مشكلات رفتارى دانش آموزان در

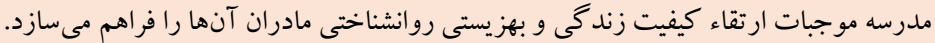

مشخصات مقاله

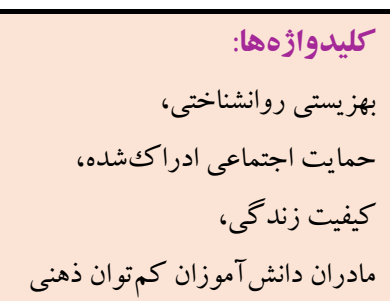

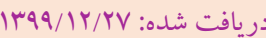

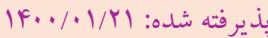

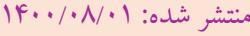

* نويسنده مسئول: خدامر اد مؤمنى، دانشيار، گروه روانشناسى، دانشكدة علوم اجتماعى، دانشگاه رازى، كرمانشاه، ايران. رايانامه: kh.momeni@razi.ac.ir 
متخصصان بسيارى معتقدند كه مشكلات رفتارى از شايعترين مسايل روانشناختى دوران كودكى و نوجوانى است (بولو تسكى ـ شرر، فانتوزو و

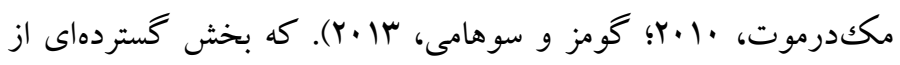

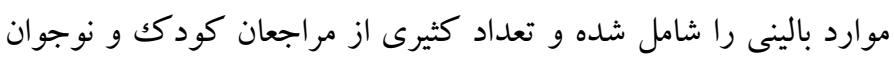

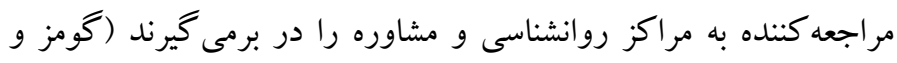

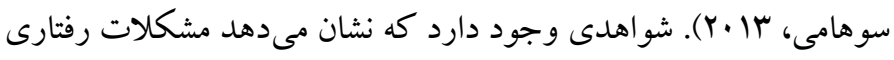

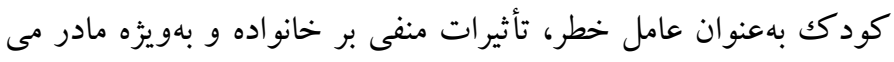

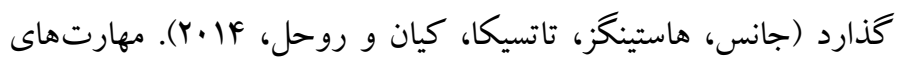

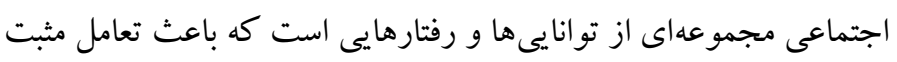

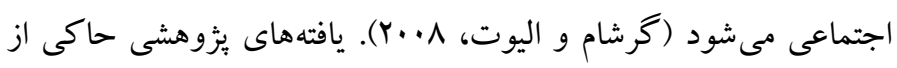

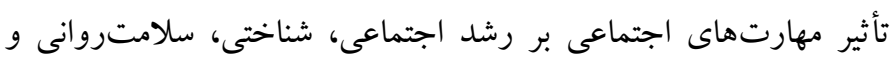

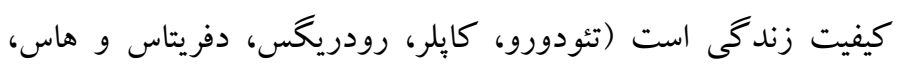

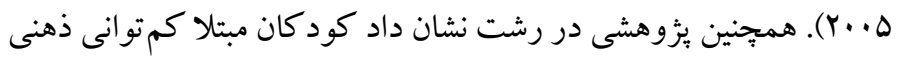
در موقعيتهاى اجتماعى بهصورت معنادارى داراى مشكلات بيشترى از

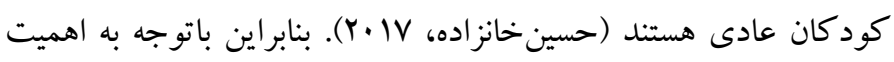
مشكلات رفتارى، مهارتهاى اجتماعى و از طرفى وجود مشكل در اين زمينه در كود كان داراى كمتوانى ذهنى، لزوم يزوهش ده در زمينه متغيرهاى

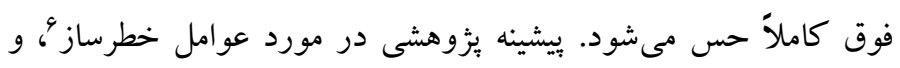
سازو كارهاى زيربنايى بهخصوص ارتباط بين متغيرهاى مربوط به كود كك

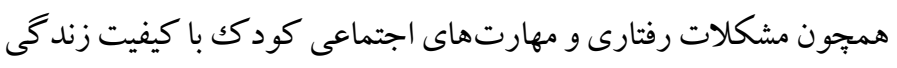

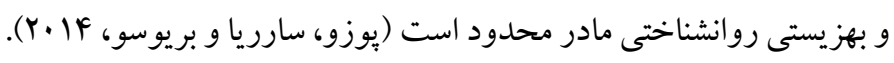
بنابراين خلاء يزٔوهشى كاملاً محسوس بوده و مطالعه در اين زمينه از اهميت

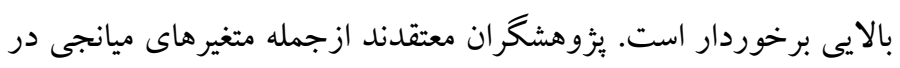

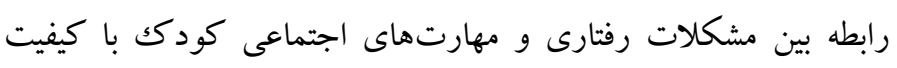

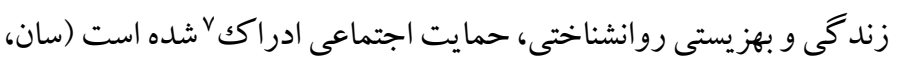

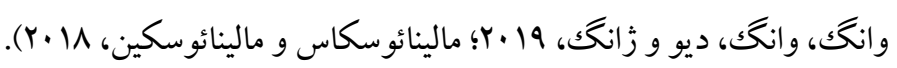
بنابراين بحث و بررسى اين متغير نيز لازم و ضرورى است.

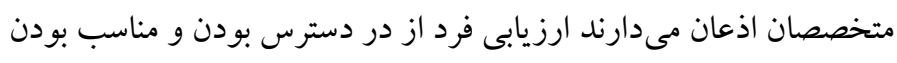
حمايت براى رفع نياز، در مواقع ضرورت و درخواست كمكك حمايت

${ }^{5}$. Social skills

${ }^{6}$. Risk Factor

7. Perceived Social Support
مقام do

كمتوانى ذهنى' يكك مشكل مهم بز شكى، روانشناسى و اجتماعى است

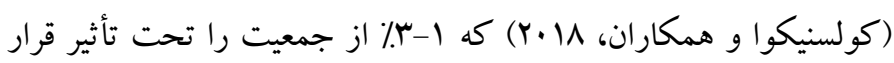

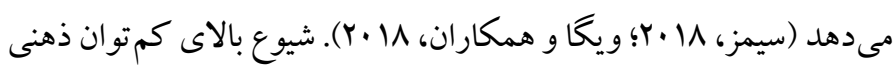

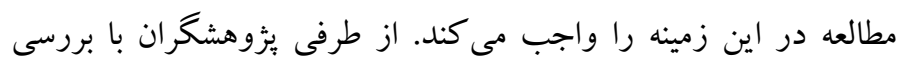

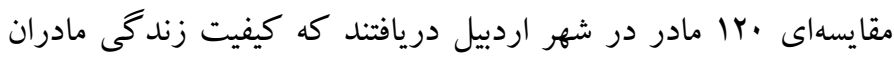

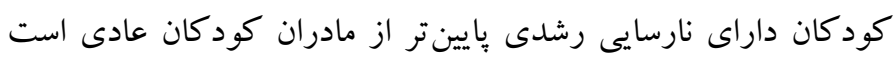

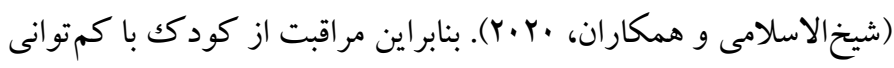

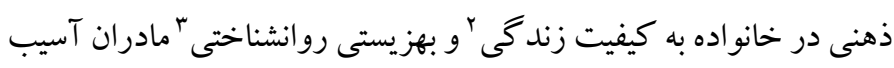

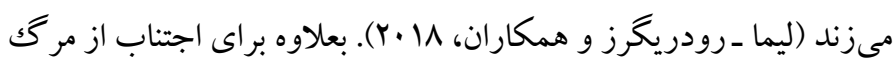

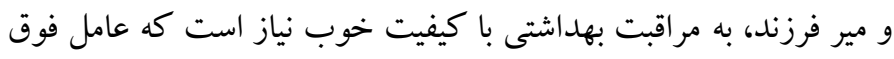

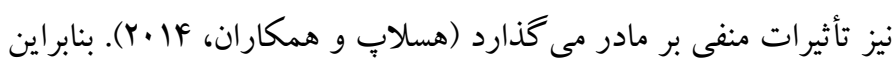
اثرات منفى ياد شده در بهزيستى روانشناختى و كيفيت زند ماتى ماتى مادران دانش آموزان كم توان ذهنى ازجمله مشكلات موجود است.

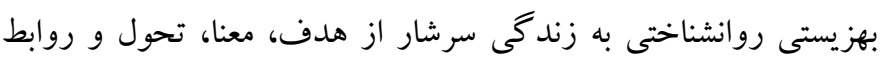

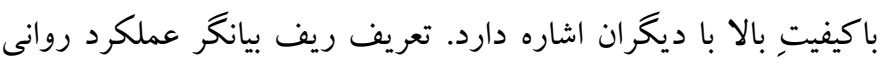

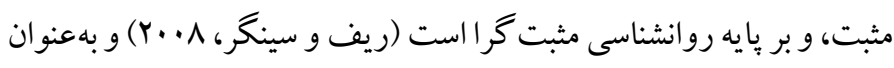
يكك عامل محافظ در برابر كشاكشهاى مختلف سلامت مانند بيرشدن زودرس بهعلت تنيدگى، بيمارىهاى قلبى عروقى و بسيارى از اختلالات

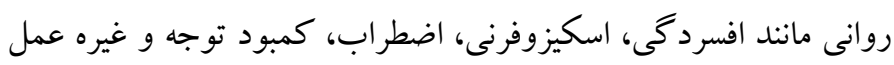

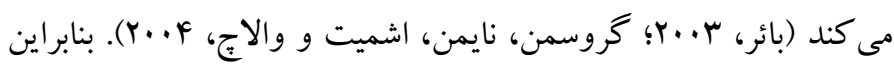
يرداختن به متغير بهزيستى روانشناختى مهم و ضرورى است. در تعريف

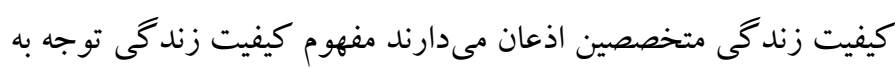

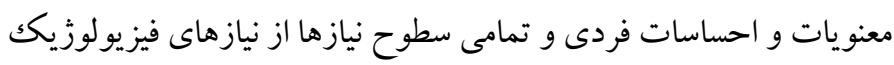

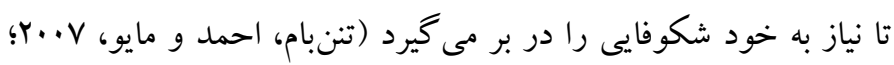

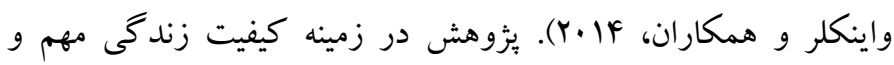
ضرورى بوده و لازم است عوامل مؤثر بر اين متغيرها همجيون مشكلات دورات

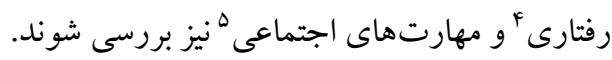

${ }^{1}$. Intellectual Disability (ID)

${ }^{2}$. Quality Of Life

3. Psychological Wellbeing

${ }^{4}$. Behavioral problems 
همكاران، 19 • (Y). بررسى 19 وروزشكار مرد نيز نشان داد حمايت اجتماعى درك شده تا حدى ارتباط بين هوش هيجانى و بهزيستى روانشناختى را

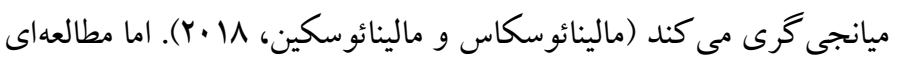
كه به نقش ميانجى كر حمايت اجتماعى ادراككشده در رابطه بين مشكلات رفتارى و مهارت هاى اجتماعى كودكى با كيفيت زندكى و بهزيستى روانشناختى مادران دانش آموزان كم توان ذهنى بيردازد، يافت نشد. بنابر اين در مطالعه فعلى يثوهشخران تصميم گرفتند نقش ميانجى گرى حمايت اجتماعى ادراككشده در رابطه مشكلات رفتارى و مهارتهاى اجتماعى كود كك با كيفيت زندكى و بهزيستى روانشناختى مادر را مورد بررسى قرار دهند. سؤالات يزٔوهش بدين صورت است: ا. آيا بين متغيرهاى مستقل (مهارتهاى اجتماعى و مشكلات رفتارى) با متغيرهاى وابسته (بهزيستى روانشناختى و كيفيت زندگى)، و نيز بين متغير ميانجى (حمايت اجتماعى ادراكشده) با متغيرهاى وابسته رابطه معنادار وجود دارد؟ r. آيا مدل ساختارى با نقش ميانجيكرى حمايت اجتماعى ادراكشده در رابطه مشكلات رفتارى و مهارتهاى اجتماعى كودك با كيفيت زندكى و بهزيستى روانشناختى مادر برازش مناسب دارد؟ ؟. آيا اثر مستقيم بين متغيرهاى مشكلات رفتارى، مهارتهاى اجتماعى و حمايت اجتماعى ادراككشده به متغير بهزيستى روانشناختى و كيفيت زندكى، همجينين مسير مستقيم بين متغيرهاى مشكلات رفتارى و مهارت هاى اجتماعى به حمايت اجتماعى ادراككشده معنادار است؟ ؟. آيا اثر غيرمستقيم متغير حمايت اجتماعى ادراكشده بين هر دو متغير مشكلات رفتارى و مهارتهاى اجتماعى كود كان با دو متغير كيفيت زندكى و بهزيستى روانشناختى مادر

معنادار است؟

روش

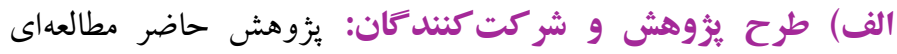

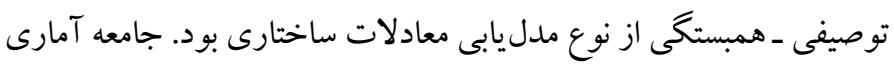

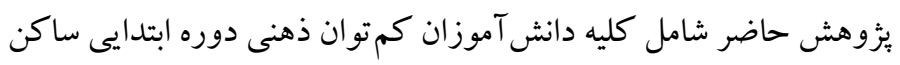

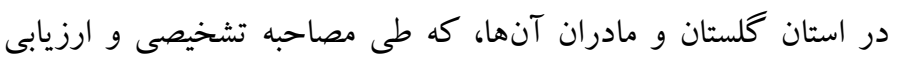

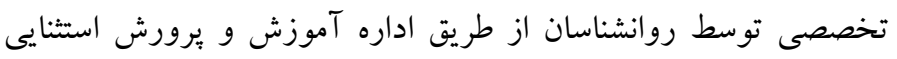

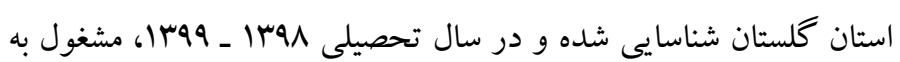

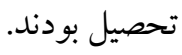

اجتماعى ادراكشده ناميده مىشود (جادويلك و كولاينز، ها+r؟؛

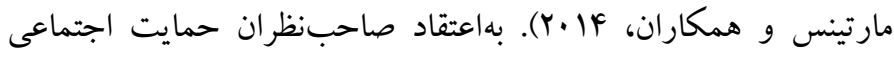

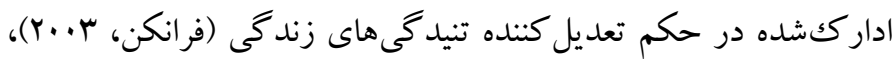

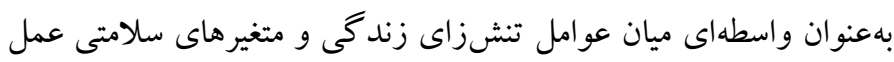
كرده، و سبب كاهش تنش، افزايش بهزيستى روانشناختى، بهبود كيفيت

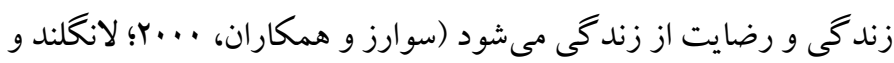

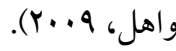

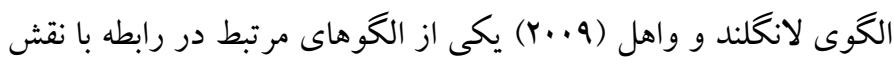

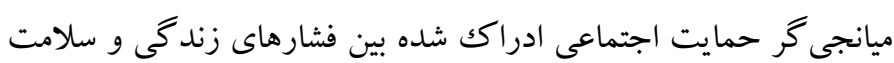

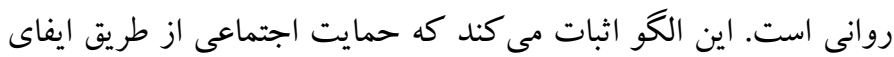

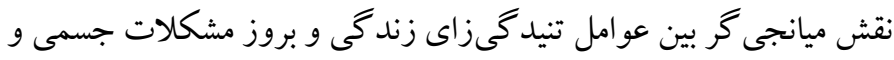

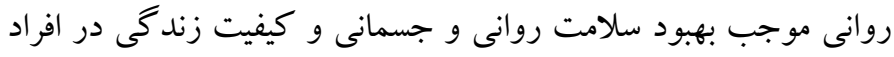

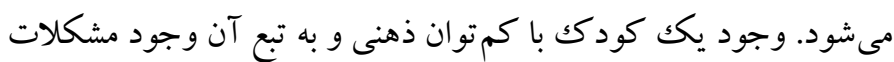
رفتارى و نقص در مهارتهاى اجتماعى كودك ازجمله عوامل تنش آور زندگى است (بوجنوسكا، رودريكز، كارسيا، آركيس و مارش، 19 ا.ب؟؛ بيير

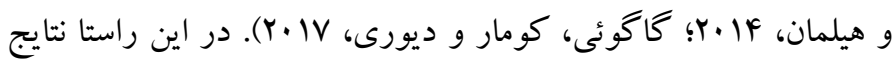

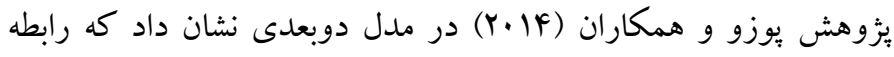

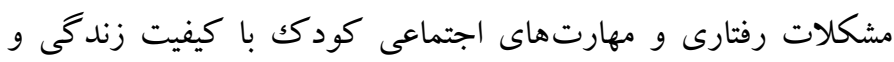
بهزيستى روانشناختى والدين از طريق حمايت اجتماعى ادراكششده

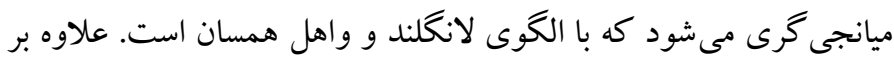
اين يافتهاى تعدادى از يثزوهشهاى ماى علمى حاكى حاكى از رابطه حمايت اجتماعى ادراكك شده با كيفيت زندگى (كاستا و همكاران،

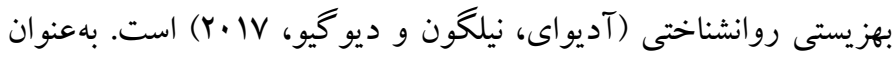

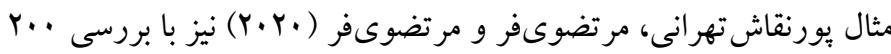

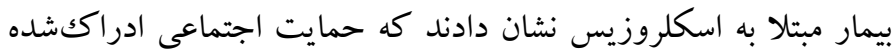

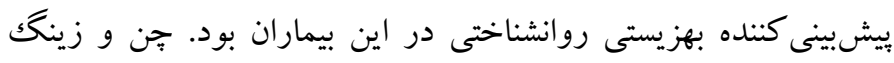
(Y.MN) افسردگى و اضطر اب بيماران بازخمهاى مزمن گرددد. در مطالعات يزوهشى حمايت اجتماعى ادراككشده بهعنوان ميانجى بين متغيرهاى مختلف بررسى شده است. بهعنوان نمونه در مطالعهاى با بررسى

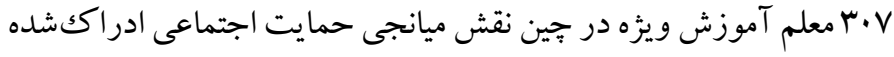

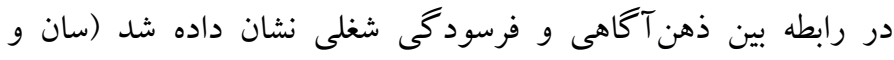


مادران با توجه به رفتارهاى فرزندشان در دوازده ماه كذشته به برسشها ياسخ مى دهند. اين برسشنامه ينج خرده مقياس برخاشگرى و فزون كنشى، اضطراب و افسردگى، ناساز گارى اجتماعى، رفتارهاى ضداجتماعى، و كمبود توجه دارد. نمره كذارى بهصورت (اصفر: درست نيست)، ("ا: تا حدى درست است)"، و (ب: كاملاً درست است)" انجام مى شود. دامنه نمرهها بين صفر تا وس است (كودينى، يورمحمدرضاىتجريشى، طهماسبى و

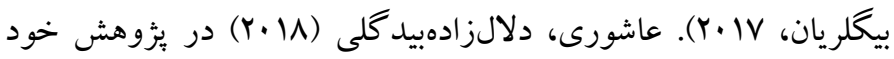
ضريب قابليت اعتماد ؟ و درستى “ّ يرسشنامه مشكلات رفتارى را بهترتيب

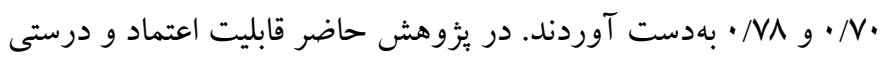
يرسشنامه بهترتيب V4/ • و Fl/ • به دست آمد. در اين بزوهش از فرم والدين برسشنامه مشكلات رفتارى راتر استفاده شد. مقياس مهارتهاى اجتماعى ماتسون f: اين مقياس در سال س1911 توسط ماتسون، اسولت ـ داوسون و كازدين براى ارزيابى مهارتهاى اجتماعى كو كان طراحى شد. فرم اوليه اين مقياس توسط يوسفى و خير (Y.... متناسب با فرهنك ايرانى هنجاريابى شده و از بو عبارت به هله عبارت كاهش يافت. مقياس فوق ينج خرده مقياس مهارت هاى اجتماعى مناسب، رفتارهاى غير اجتماعى، برخاشخرى و رفتارهاى تكانشى، برترىطلبى و اطمينان زياد به خود، و رابطه با همسالان) را در بر مى كيرد (ماتسون و همكاران، سي191). سؤالهاى يرسشنامه در مقياس ليكرت ه درجهاى (از هر گز =ا، تا هميشه =(ه) ارزيابى مى شود. شيوه نمره كذارى در سؤالات

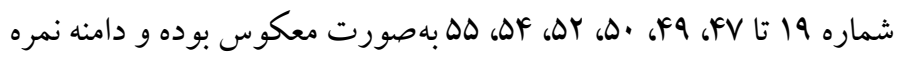
ها از ها تا هV تحقيقات نشان مىدهد مقياس مهارت هاى اجتماعى ماتسون از ويثز روان سنجى قابل قبولى برخوردار است (ماتسون و همكاران، سه9 (). قابليت اعتماد مقياس در يُووهشهاى بررسى شده مقدار قابل قبول را نشان داد

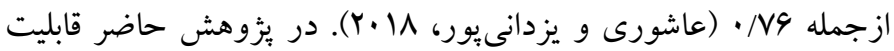
اعتماد و درستى برسشنامه بهترتيب Y9/ • و M / • به دست آمد. مقياس جندبعدى حمايت اجتماعى ادراكك شده ه: اين مقياس در سال 19M 19M توسط زيمت و همكاران بهمنظور سنجش حمايت اجتماعى ادراكى شده تهيه كردهاند. اين مقياس rا گويه دارد و مشتمل بر سه زير مقياس خانواده،

4. Matson's social skills scale

5. Multidimensional Scale of Perceived Social Support (MSPSS)
براى تعيين اندازه نمونه كلاين (19 +19) نسبت ·r نفر به ازاى هر متغير را مطرح مى كند و اذعان مىدارد كه به اين تعداد بايد ها ٪\% تعداد كل بهدست آمده را افزود. حجم نمونه در نمونههايى از يزوهش هاى مدليابى معادلات ساختارى در والدين كودكان با نيازهاى ويثه بدينقرار است: يوزو و

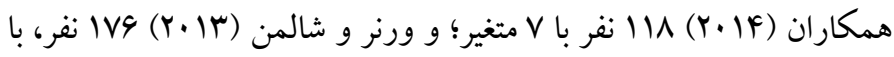
ها متغير. با استناد به يافته هاى فوق در اين بثروهش نمونهاى به حجم نفر در نظر كر فته شد. كه بهعلت ناهمخن. بودن گرووها، عدم دسترسى به

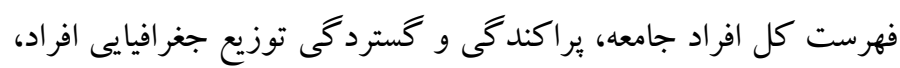
نمونه مورد نظر به روش نمونه گيرى خوشهاى جندمر حلهاى انتخاب شدند. بدينصورت كه ابتدا دو ناحيه شرق و غرب براى استان در نظر گرفته شد. سيس از هر ناحيه به تصادف، ه مدرسه (انتخاب ·ل مدرسه از ·r مدرسه داراى دانش آموز با كم توانى ذهنى دوره ابتدايى) انتخاب شدند. سپس از هر يكك از يايههاى دوره ابتدايى بهصورت تصادفى دانش آموزان انتخاب شدند. يس از آن دادهها با ابزارهايى كه در ادامه مى آيند جمع آورى شده و سبس دادههاى حاصل با آمار توصيفى، آزمون همبستكى بيرسون و مدل يابى معادلات ساختارى تحليل شدند. ملاككهاى ورود و خروج نمونه براساس هدف ئزوهش و نيز با الكو گيرى از يزٔوهشهاى بيشين مدليابى معادلات ساختارى در والدين كود كان با

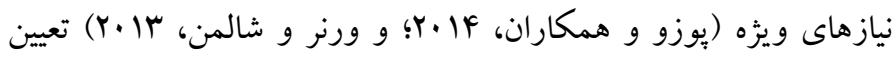
شدند. ملاككهاى ورود افراد براى شركت در بثزوهش شامل داشتن فرزند با كم توانى ذهنى و شاغل در مدرسه در دوره ابتدايى، رده سنى . ب ـ سال براى مادران، تنى بودن مادر، رضايت مادران جهت شر كت در بثزوهش بود. و ملاككهاى خروج افراد در بثروهش شامل مشغول به تحصيل بودن دانش آموز در دورههاى تحصيلى بالاتر و يايينتر از ابتدايى، و ناتنى بودن مادر بود. ابزارهاى استفاده شده در بزوهش شامل موارد زير است.

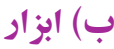
يرسشنامه مشكلات رفتارى كود كان راتر ': اين برسشنامه در سال 199V توسط راتر براى سنجش مشكلات رفتارى و عاطفى كود كان در قالب دو فرم والدين و معلم طراحى شده است. فرم والدين شامل \1 سؤال است كه

1. The Rutter Children's behavior questionnaire

2. Reliability

${ }^{3}$. Validity 
زندگى و خودمختارى دارد. نمره گذارى آن براساس ليكرت 9 درجهاى

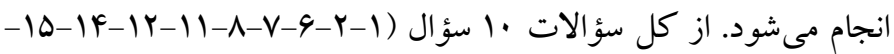

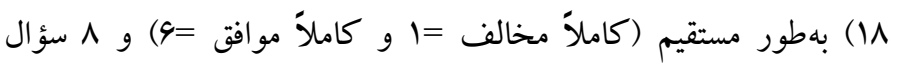

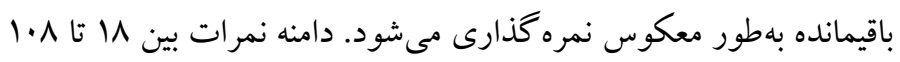

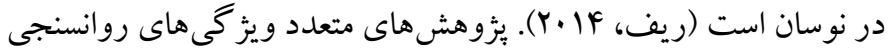

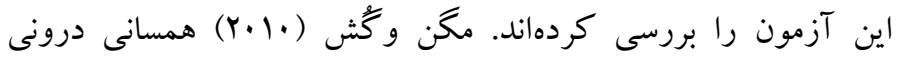

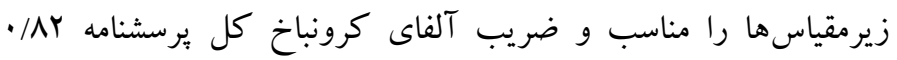

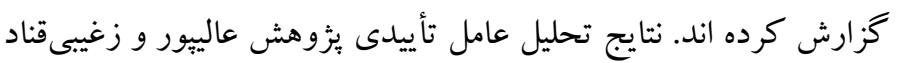

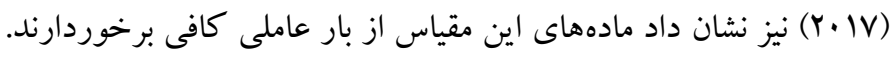
در بزوهش حاضر قابليت اعتماد و درستى برسشنامه بهترتيب VA/ و و V9/. به دست آمد.

يافته ها

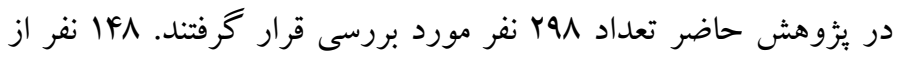

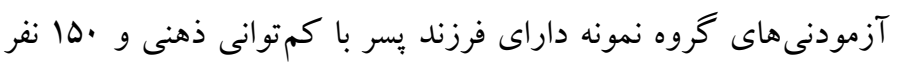
داراى فرزند دختر با كمتوانى ذهنى بودند. در جدول إست شاخص هاى

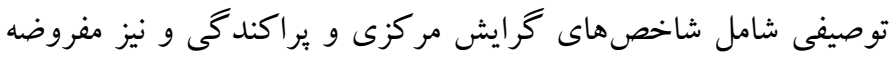
هاى نرمال بودن بررسى شده و نتايج آن در اين جدول قيد شده است

\begin{tabular}{|c|c|c|c|c|}
\hline $\mathrm{KU}$ & SK & SD & M & متغير ل \\
\hline$\cdot / \mathrm{Ar}-$ & $\cdot /$ rA- $^{-}$ & $r \cdot / \Delta 9$ & $9 \cdot 190$ & ا. بهزيستى روانشناختى \\
\hline •/Ar- & $\cdot / \cdot r-$ & $r \cdot 199$ & GY/A9 & r. كيفيت زندگى \\
\hline l/Tr- & $\cdot / \cdot F-$ & $1 r / r q$ & $r \Delta / r r$ & r. حمايت اجتماعى \\
\hline$\cdot / v \cdot-$ &.$/ 19$ & V/ar & $r Y / \cdot q$ & F F. مشكلات رفتارى \\
\hline$\cdot / 11$ & $\cdot / \cdot r-$ & $Y V / F V$ & $1.9 / \Delta \Delta$ & ه. مهارت هاى اجتماعى \\
\hline
\end{tabular}

همانطور كه جدول ا نشان مىدهد، شاخصهاى كجى و كشيدگى براى بررسى مفروضه نرمال بودن توزيع متغيرهاى ئزوهش مورد بررسى قرار

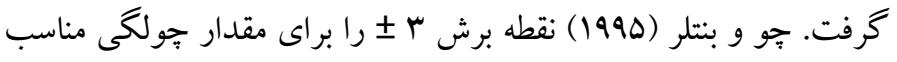

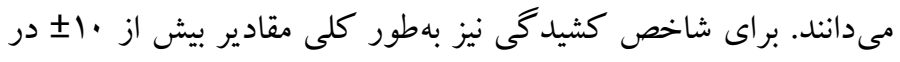

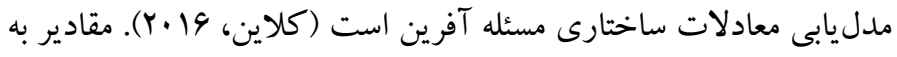

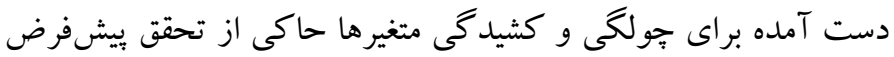

2. Ryff Psychological Wellbeing Scale (RPWBS)
دوستان و افراد مهم زندگى است. سؤالهاى برسشنامه براساس مقياس ه

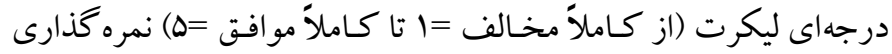

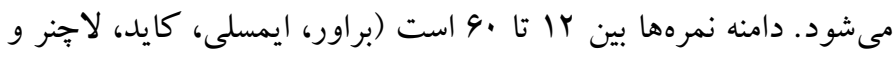

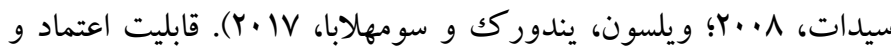
درستى اين مقياس توسط ويلسون و همكاران (Y.IV) در حد مطلوب

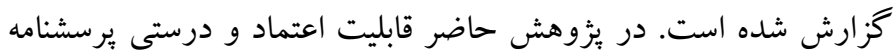

$$
\text { به ترتيب NA/ • و ه ه • به دست آمد. }
$$

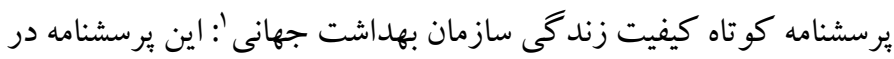
سال l994 به كوشش عدهاى از ئزوهشخران زير نظر سازمان جهانى بهداشت براى ارزيابى كيفيت زندگى افراد ساخته شد. اين مقياس بين

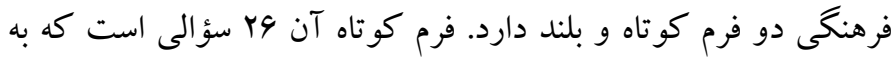

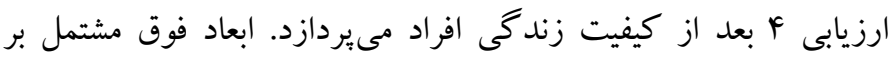

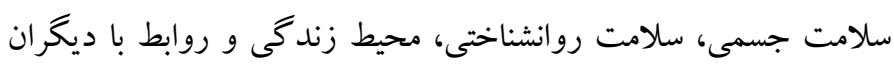

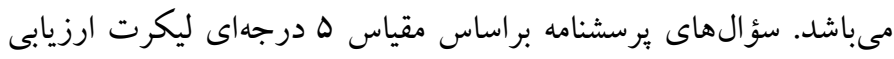

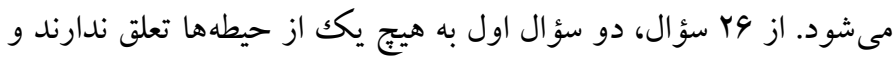
وضعيت سلامت و كيفيت زندگى را بهطور كلى مىسنجند. بنابراين

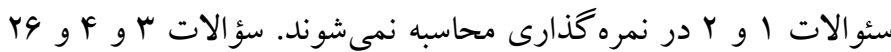

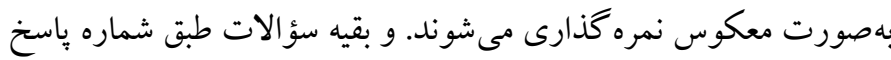

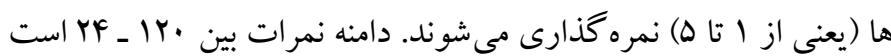
(نجات، منتظرى، هلاكوئىنائينى، محمد و مجدزاده، 9. +Y). قابليت اعتماد

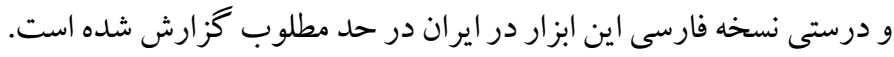

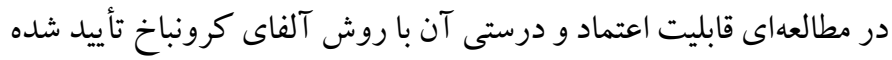

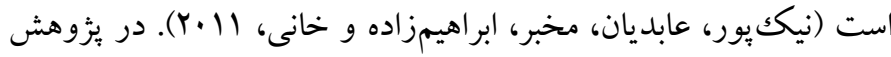
حاضر قابليت اعتماد و درستى برسشنامه بهترتيب M// • هـ/· به دست

مقياس بهزيستى روانشناختى ريف ؟: اين مقياس در سال •191 توسط ريف،

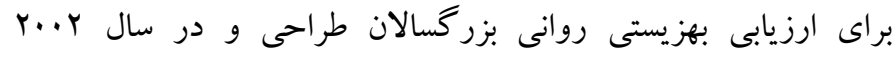

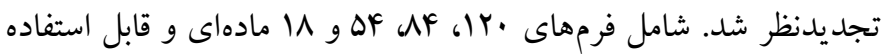

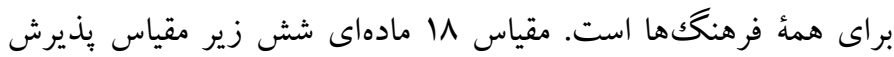

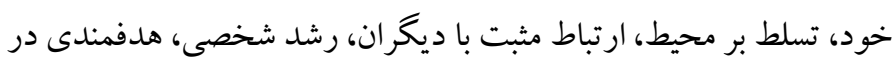

1. World Health Organization Quality Of Life (WHOQOLBREF) 
(بهزيستى روانشناختى و كيفيت زندكى)، با متغير ميانجى (حمايت اجتماعى ادراككشده) و نيز رابطه بين متغيرهاى وابسته با يكديكر، و با متغير ميانجى معنادار است و تمام اين روابط در سطح 1 • • معنادار مىباشد. بنابراين در باسخ به سؤال اول يزٔوهش مى توان كفت آرى بين متغيرهاى مستقل با متغيرهاى وابسته، و نيز بين متغير ميانجى با متغيرهاى وابسته رابطه معنادار وجود دارد. علاوه بر اين رابطه بين متغيرهاى مستقل با يكديكر و با متغير ميانجى و نيز رابطه بين متغير هاى وابسته با يكديخر معنادار است و تمام اين

$$
\text { روابط در سطح } 1 \text { •/ • معنادار مىباشد. }
$$

در ادامه براى بررسى اثرهاى مستقيم و واسطهاى از روش مدلسازى معادلات ساختارى استفاده شد كه نتايج آن در قالب شكل ا و جداول

$$
\text { اثرات مستقيم و غيرمستقيم ارائه مىشود. }
$$

در شكل ا مسيرهاى معنادار بهصورت ممتد و مسيرهاى غير معنادار به

$$
\text { صورت خطوط غيرممتد نشان داده شدهاند. }
$$

در ادامه شاخصهاى برازش مدل ساختارى در جدول F نشان داده شده است. همان گونه كه مندرجات اين جدول نشان مىدهد شاخصهاى برازش مدل ساختارى نشانكر برازش مناسب مدل است. تمام شاخصهاى مدل در محدوده يذيرش مدل قرار دارند، بنابراين ساختار مدل فرضى يثزوهش مورد تأييد مىباشد. و در ياسخ به سؤال دوم يثزوهش مى توان كفت مدل ساختارى با نقش ميانجى گرى حمايت اجتماعى ادراككشده در رابطه مشكلات رفتارى و مهارتهاى اجتماعى كودك با كيفيت زندكى و بهزيستى روانشناختى مادر برازش مناسب دارد.
نرمال بودن در متغيرهاى يثو هش دارد. براى بررسى مفروضهُ عدم هم خطى از آمارههاى عامل تورم واريانس (VIF) و شاخص تحمل نيز استفاده شد كه با توجه به اينكه هيج يكك از مقادير مربوط به شاخص تحمل كمتر از 1 • • و هيج يكك از مقادير مربوط به عامل تورم واريانس بيشتر از • انمى باشد، بر اين اساس مىتوان نسبت به مفروضه عدم همخطى نيز اطمينان حاصل كرد. در جدول زير شاخص تحمل، عامل تورم واريانس و استقلال

\begin{tabular}{|c|c|c|c|}
\hline دوربينواتسون & عامل تورم وايانس & تحمل & متغير \\
\hline \multirow{3}{*}{$1 / 9 V r$} & r/rAD &.$/ 79 \Delta$ & مشكلات رفتارى \\
\hline & $f / r / F$ & 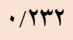 & مهارتهاى اجتماعى \\
\hline & $\Delta / \Delta 1$ & $\cdot / \backslash \wedge 1$ & حمايت اجتماعى \\
\hline
\end{tabular}
خطاها براى متغير هاى يزٔوهش ارائه شده است.

جدول r. شاخص تحمل، عامل تورم واريانس و استقلال خطاها براى متغير هاى

\begin{tabular}{|c|c|c|c|c|c|}
\hline$\Delta$ & F & $r$ & r & 1 & متغير \\
\hline & & & & 1 & I. بهزيستى روانشناختى \\
\hline & & & 1 & $* * . / 91$. & r. كيفيت زندكى \\
\hline & & 1 & $* *$. /A^V & $* * \cdot / \Lambda \cdot V$ & r. حمايت اجتماعى \\
\hline & 1 & **./VFG- & $* * \cdot / \wedge \mid V-$ & $* * \cdot|\wedge 9|-$ & F. مشكلات رفتارى \\
\hline 1 & $* * \cdot / \wedge \mid \wedge-$ & $* * . / \vee q$ & $* *, / \Lambda F F$ & $* * \cdot / \wedge \mathrm{VI}$ & هـ مهارتهاى اجتماعى \\
\hline
\end{tabular}

در جدول زير همبستخى ييرسون متغيرهاى يزوهش ارائه شده است. جدول r. ماتريس همبستغى بيرسون متغير هاى بثزوهش

$$
* * \mathrm{P}<\cdot / \cdot 1 * \mathrm{P}<\cdot / \cdot \Delta
$$

همانطور كه مندرجات جدول بنشان مىدهد رابطه بين متغيرهاى مستقل (مهارت هاى اجتماعى و مشكلات رفتارى) با يكديگر، با متغيرهاى وابسته

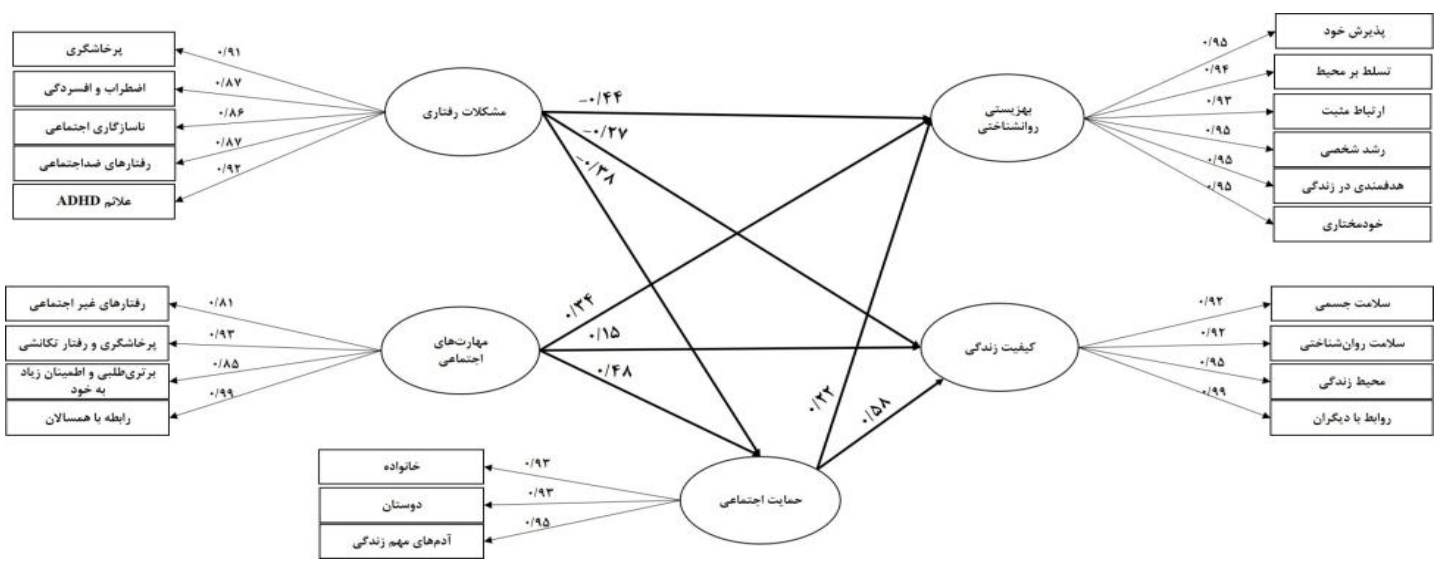

شكل ا. مدل مفهومى ثخؤش به همراه ضرايب مسير استاندارد متغيرهاى ثئوهش در مدل اصلى 
است يا سطح معنادارى آنها كمتر از ه•/ • است تأثير معنادارى بر متغير وابسته دارند. بنابراين مسير مستقيم تمام متغيرهاى مستقل در جدول با متغيرهاى وابسته معنادار است. بهعنوان مثال مسير مستقيم بين متغيرهاى

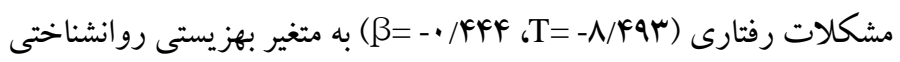
معنادار است. بنابراين در ياسخ به سؤال سوم يثروهش مىتوان كفت اثر مستقيم بين متغيرهاى مشكلات رفتارى، مهارتهاى اجتماعى و حمايت اجتماعى ادراككشده به متغير بهزيستى روانشناختى و كيفيت زندكى، همجينين مسير مستقيم بين متغيرهاى مشكلات رفتارى و مهارتهاى

اجتماعى به حمايت اجتماعى ادراككشده معنادار است. در ادامه جدول 9 اثر ميانجى متغير حمايت اجتماعى ادراككشده در رابطهى بين مشكلات رفتارى و مهارتهاى اجتماعى كود كان با كيفيت زندكى و بهزيستى روانشناختى مادر، از طريق روش بوت استرب با ... ب بار فر آيند نمونه گيرى و با فاصلة اطمينان هو درصد را كز ارش مى كند.
جدولع. شاخص هاى برازش مدل ساختارى

\begin{tabular}{|c|c|c|}
\hline مقدار & دامنه قابل يذيرش & شاخص برازندگى \\
\hline $494 / 111$ & - & خىدو (每) \\
\hline$r / r \Delta \wedge$ & كمتر از ب ك & نسبت خىدو به درجه آزادى \\
\hline$\cdot / 9 \vee \Delta$ & 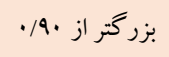 & شاخص برازندكى تطبيقى(CFI) \\
\hline$\cdot / 9 \vee \Delta$ & 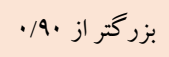 & شاخص برازند گى فز آينده(IFI) \\
\hline$\cdot / 9 \vee$ & 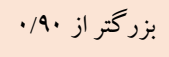 & شاخص تو كر-لويس (TLI) \\
\hline .1 .91 & 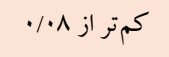 & ريشه دوم بر آورد واريانس خطاى تقريب (RMSEA) \\
\hline.$/ \mathrm{kr}$ & 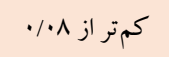 & ريشه دوم ميانخين مربعات باقىمانده (SRMR) \\
\hline$\Delta V G / \wedge I \Lambda$ & - & معيار اطلاعاتى آكايكه (AIC) \\
\hline
\end{tabular}

در ادامه نتايج جدول هو 9 اثرات مستقيم و واسطهاى متغيرهاى يثوهش را نشان مىدهد و بر اساس آن مى توان به تأييد يا رد اثرات مستقيم و غيرمستقيم متغيرهاى بثزوهش برداخت. همانطور كه در جدول ه مشاهده مىشود تمام متغيرهايى كه مسيرهاى

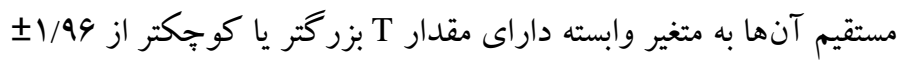

جدوله. بروسى روابط مستقيم متغير ها در مدل يخوهش

\begin{tabular}{|c|c|c|c|c|c|c|}
\hline$P$ & $\mathrm{~T}$ & خطاى استاندارد & ضريب غير استاندارد & ضريب استاندارد & متغير وابسته & متغير مستقل \\
\hline.$/ .1$ & $-\Lambda / \& q \mu$ &.$/ 14 \mathrm{r}$ & $-1 / 194$ & $-\cdot / F F F$ & بهزيستى روانشناختى & مشكلات رفتارى \\
\hline.$/ \cdot 1$ & $9 / 9 \mathrm{VI}$ &.$/ .4 q$ & . TS4 & $\cdot / \pi T V$ & بهزيستى روانشناختى & مهارتهاى اجتماعى \\
\hline.$/ .1$ & $F / A . q$ & .1 .49 &.$/$ VVD & $\cdot /$ IIV & بهزيستى روانشناختى & حمايت اجتماعى \\
\hline.$/ \cdot 1$ & $-\Delta / r M \Lambda$ & $\cdot / r \cdot \Delta$ & $-1 / \cdot \sqrt{ } 1$ & $-\cdot / 499$ & كيفيت زندگى & مشكلات رفتارى \\
\hline$\% \mu$ & Y/AMF & .1 .4 &.$/ \mathrm{Vr}$ &.$/ 149$ & كيفيت زندگى & مهارتهاى اجتماعى \\
\hline.$/ \cdot 1$ & $11 / \wedge \Delta 9$ & .1 .9 & $\cdot / v \cdot 9$ & $\cdot / \Delta V \wedge$ & كيفيت زندگى & حمايت اجتماعى \\
\hline$\cdot / \cdot 1$ & $-\Delta / r V F$ & $\cdot / r \mu F$ & $-1 /$ rMF & $-\cdot / \mu \wedge$ & حمايت اجتماعى & مشكلات رفتارى \\
\hline.$/ \cdot 1$ & g/ATI & .1 .91 &.$/ 494$ & . / FAY & حمايت اجتماعى & مهارتهاى اجتماعى \\
\hline
\end{tabular}

\begin{tabular}{|c|c|c|c|c|c|c|}
\hline$P$ & حد بالا & حل هايين & $\mathrm{b}$ & متغير وابسته & متغير ميانجى & متغير مستقل \\
\hline$\cdot / \cdot r$ & $-\cdot / \cdot \wedge F$ & $-\cdot / \Delta r$. & $-\cdot / Y 19$ & بهزيستى روانشناختى & حمايت اجتماعى & مشكلات رفتارى \\
\hline $.1 \cdot 11$ & $-\cdot /$ rAr & $-1 / F \Delta 1$ & $-\cdot / \wedge \vee \Delta$ & كيفيت زندگى & حمايت اجتماعى & مشكلات رفتارى \\
\hline 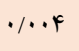 & $\cdot / 199$ & $\cdot / \cdot r V$ & / /Ar & بهزيستى روانشناختى & حمايت اجتماعى & مهارتهاى اجتماعى \\
\hline$\% \cdots \wedge$ & . $/ \Delta T V$ & $\cdot / r \cdot \Lambda$ & 1 ו וח/. & كيفيت زندگى & حمايت اجتماعى & مهارتهاى اجتماعى \\
\hline
\end{tabular}

غيرمستقيم متغير حمايت اجتماعى ادراككشده بين هر دو متغير مشكلات

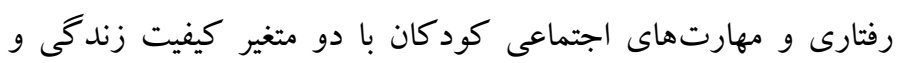
بهزيستى روانشناختى مادر معنادار است.
با توجه به جدول 4 مىتوان مشاهده كرد كه اثر غيرمستقيم متغير حمايت اجتماعى ادراككشده بين هر دو متغير مشكلات رفتارى و مهارتهاى اجتماعى كود كان با دو متغير كيفيت زندكى و بهزيستى روانشناختى مادر معنادار است. بنابر اين در يّاسخ به سؤال جهارم يثزوهش ميى توان كفت اثر 


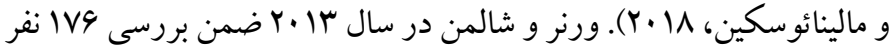

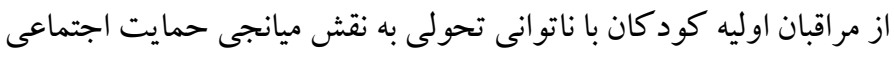

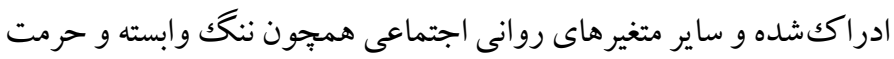

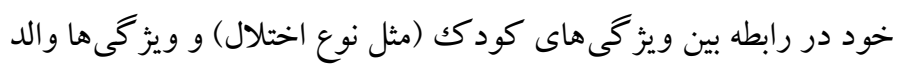

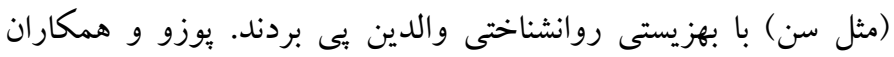

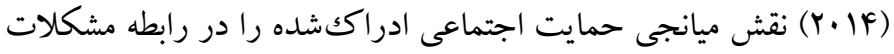

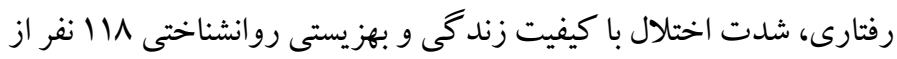

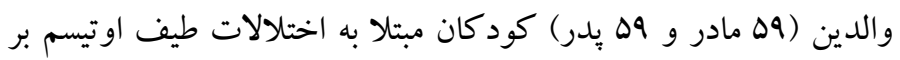
اساس مدل دوبعدى مطالعه كردند. آنها دريافتند حمايت اجتماعى در رابطه با متغيرهاى ذكر شده بهعنوان يكك ميانجى ايفاى نقش

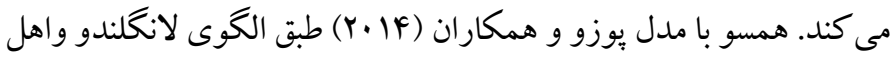

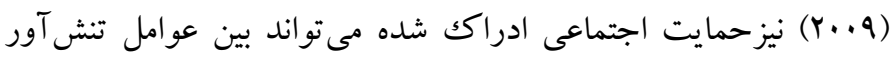

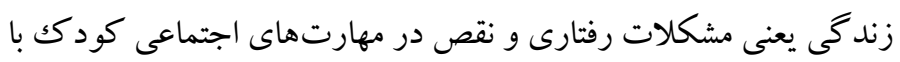

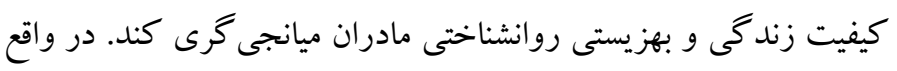

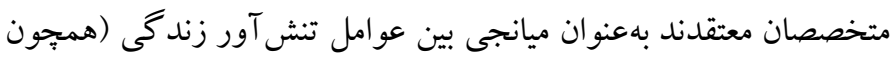
مشكلات يكك كود كى كم توان ذهنى) و متغيرهاى سلامتى عمل كرده، و و

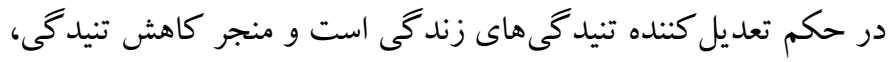

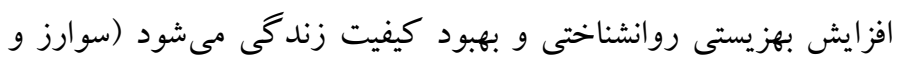

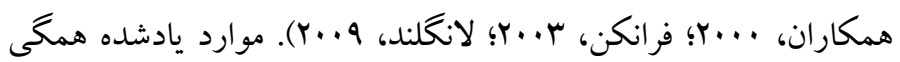
حاكى از تأييد نتايج يُزوهش با بيشينه يزوهشى و نظرى قوى مى باشد.

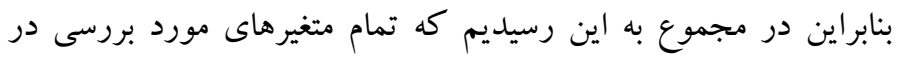

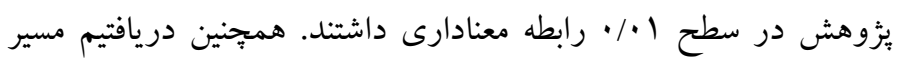
مستقيم بين متغيرها معنادار بوده علاوه بر اين اثر غيرمستقيم متغير حمايت

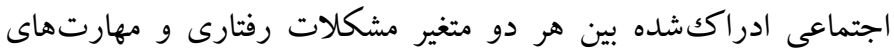

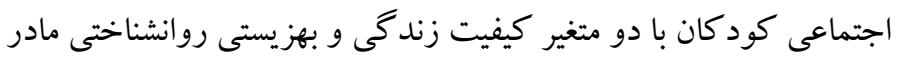

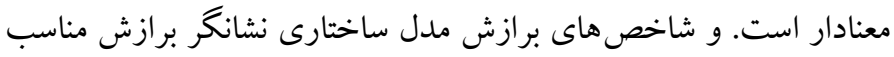

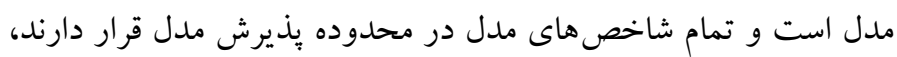

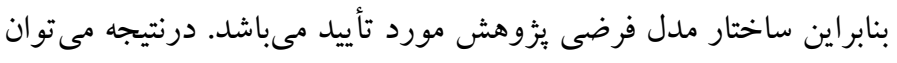

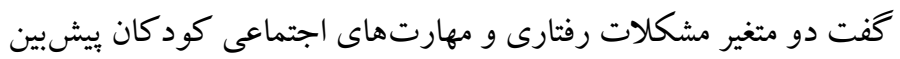

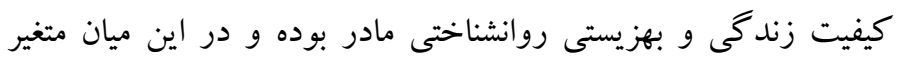
حمايت اجتماعى ادراككشده نقش ميانجى ايفا مى كند. براساس يافته هاى

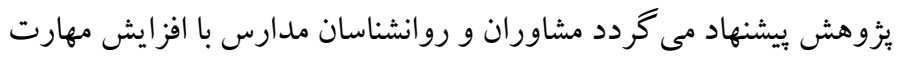

بحث و نتيجه تيرى تحليل يافتهاى يُزوهش حاكى از رابطه معنادار بين متغيرهاى مهارتهاى

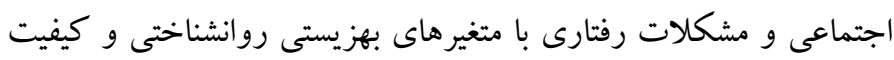

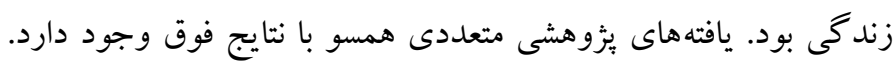

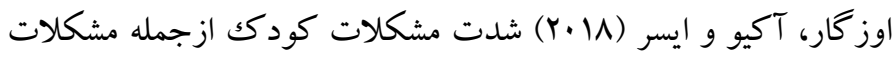

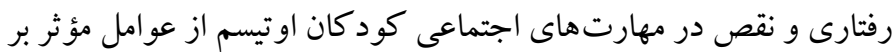

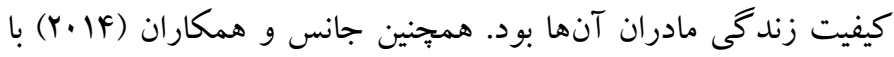
بررسى المادر و qه بدر از والدين كود كان مبتلا به اتيسم به رابطه مستقيم مشكلات رفتارى كودكان با بهزيستى روانشناختى والدين بيى بردند.

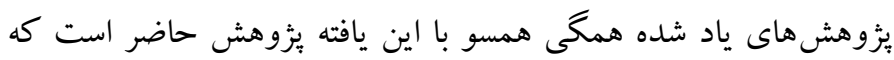
رابطه معنادار بين متغيرهاى مهارتهاى اجتماعى و مشكلات رفتارى با بال متغير هاى بهزيستى روانشناختى و كيفيت زندكى وجود دمائ دارد.

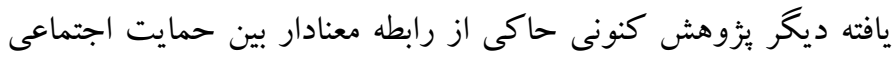

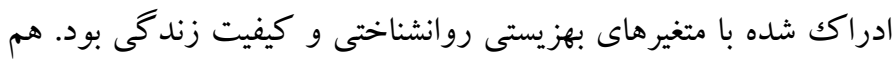
راستا با يافته فوق يزوهشهاى زيادى از رابطه مثبت و مستقيم حمايت

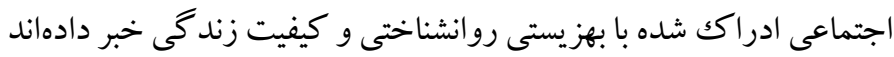

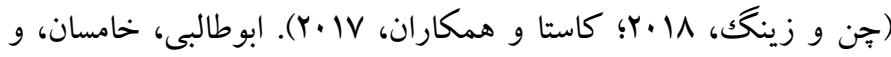

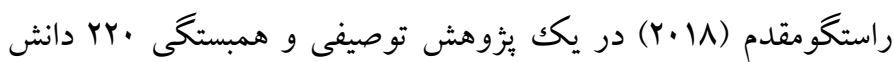
آموزان دختر مقطع بيشدانشگاهى شهر بير جند را مورد مطالعه قرار دادند.

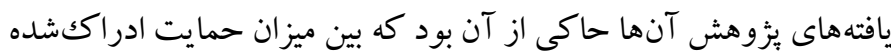
از سوى والدين و هم كلاسىها با بهزيستى ذهنى رابطه مثبت و معنادار

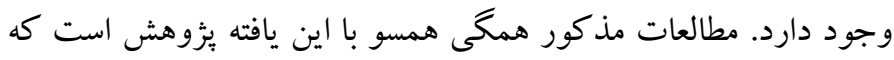

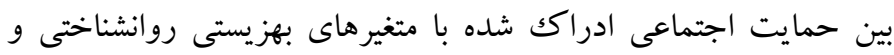
كيفيت زندگى رابطه معنادار وجود دارد.

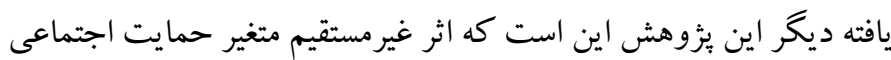
ادراككشده بين هر دو متغير مشكلات رفتارى و مهارتهاى اجتماعى كود كان با دو متغير كيفيت زندگى و بهزيستى روانشناختى مادر معنادار

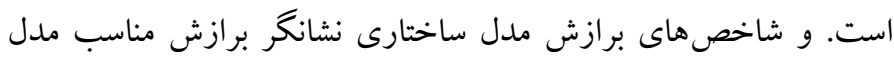
است و تمام شاخصهاى مدل در محدوده يذيرش مدل قرار دارند، بنابر اين

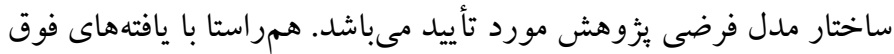
متخصصان بسيارى نقش ميانجى گرى حمايت اجتماعى ادار ككشده را بين متردين

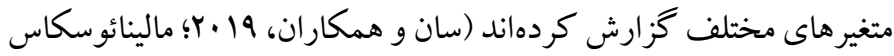


يثزوهش در جامعه آمارى از طرف اداره كل آموزش و يرورش استان گلستان صادر شده

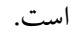

حامى مالى: اين يثزوهش در قالب رساله دكترى و بدون حمايت مالى مىباشد. نقش هر يكك از نويسند كان: نويسنده اول محقق اصلى اين يثزوهش است. نويسنده دوم استاد راهنما و نويسند كان سوم و جهارم استادان مشاور رساله مى باشند. تضاد منافع: نو يسندكان هيج تضاد منافعى در رابطه با اين بثزوهش اعلام نمىنمايند. ت شكر و قدروانى: بدينوسيله از اسـاتيد محترم راهنما و مشـاوران اين يثزوهش، اداره كل آموزش و يرورش ا ستان گلمستان، اداره آموزش و بيرورش ا ستثنايى استان كلمتان،

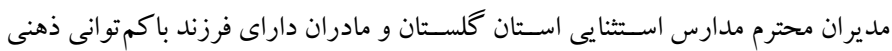

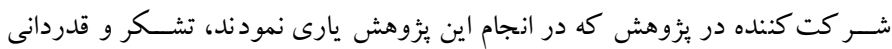
مى گردد.
هاى اجتماعى و كاهش مشكلات رفتارى دانش آموزان در مدرسه موجبات ارتقاء كيفيت زندكى و بهزيستى روانشناختى مادران دانش آموزان را فراهم نمايند. طبق نظر يوزو و همكاران (Y.|F) استفاده از يرسشنامههاى خودگزارشى محدوديت يزوهش به شمار مى آيد. در يزٔوهش حاضر اين محدوديت مشهود است. بهعبارتى خود گزارشى بودن برسشنامه هاى مورد

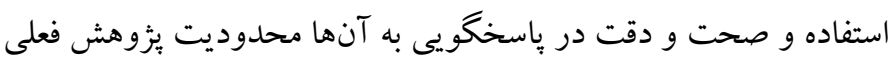

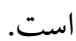

ملاحضات اخلاقى ييروى از اصول اخلاق يُوهش: اين مقاله بر گرفته از ر ساله دكترى نويسنده اول، در رشته روانشناسى دانشگاه رازى كرمانشاه است. مشار كت كنند گان آكاهانه و داوطلبانه

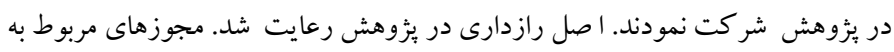




\section{References}

Abootalebi, F., khamesan., \& rastgoumoghadam. (2018). The Relationship between Perceived Social Support with Subjective Well-Being and Academic Achievement of Female Pre-University Students. Quarterly of Educatinal Psychology, 14(8), 147168. (Persian). [link].

Alipoor, S., \& Zeqeibi Ghannad, S. (2017).Investigation of the Relationship of Mindfulness with Psychological Well-being: The Role of Strategic Engagement Regulation and Self-Esteem. Positive Psychology Research, 3(2), 1-18. (Persian). [link].

Ashori, M., \& Dallalzadeh Bidgoli, F. (2018). The Effectiveness of Play Therapy Based on CognitiveBehavioral Model: Behavioral Problems and Social Skills of Pre-School Children With Attention Deficit Hyperactivity Disorder. Jrehab, 19(2), 102115. (Persian). [link].

Ashori, M., \& Yazdanipour, M. (2018). Investigation of the Effictiveness of Group Play Therapy Training With Cognitive-Behavioral Approach on the Social Skills of Students With Intellectual Disability. Jrehab, 19(3), 262-275. (Persian). [link].

Baer, R.A. (2003). Mindfulness training as a clinical intervention: A conceptual and empirical review. Clinical Psychology: Science and Practice, 10(2), 125-142. [Link].

Bujnowska, A.M., Rodriguez, C., Garcia, T., Areces, D., \& Marsh, N.V. (2019). Parenting and Future Anxiety: The Impact of Having a Child with Developmental Disabilities. International journal of environmental research and public health, 16(4), 668-691. [Link].

Bulotsky-Shearer, R.J., Fantuzzo, J.W., \& McDermott, P.A. (2010). Typology of emotional and behavioral adjustment for low income children: A childcentered approach. Journal of Applied Developmental Psychology, 31, 180-191. [Link].

Bruwer, B., Emsley, R., Kidd, M., Lochner, C., \& Seedat, S. (2008). Psychometric properties of the Multidimensional Scale of Perceived Social Support in youth. Comprehensive Psychiatry, 49(2), 195-201. [Link].

Chadwick, K.A., \& Collins, P.A. (2015). Examining the relationship between social support availability, urban center size, and self-perceived mental health of recent immigrants to Canada: a mixed-methods analysis. Social Science \& Medicine, 128, 220-230. [Link].
Chen, Y., \& Zeng, Y. (2018). Correlation of depression and anxiety with social support and quality of life in patients with chronic wounds. Zhong Nan Da Xue Xиe Bao Yi Xue Ban, 43, 1032-1036. [Link].

Chou, C.P., \& Bentler, P. M. (1995). Estimates and tests in structural equation modeling. In R. H. Hoyle (Ed.), Structural equation modeling: Concepts, issues, and applications (p. 37-55). Sage Publications, Inc. [Link].

Costa, A.L.S., Heitkemper, M.M., Alencar, G.P., Damiani, L.P., Silva, R.M.D., \& Jarrett, M.E. (2017). Social support is a predictor of lower stress and higher quality of life and resilience in Brazilian patients with colorectal cancer. Cancer Nurs, 40, 352-360. [Link].

Franken, R. (2003). Human motivation. $5^{\text {th }}$ ed. United States; Academic Internet Publishers Incorporated. Wadsworth/Thomson Learning pp: 529. [Link].

Gogoi, R., Kumar, R., \& Deuri, S. (2017). Anxiety, depression, and quality of life in mothers of children with intellectual disability. Open Journal of Psychiatry and Allied Sciences, 8(1),71-75. [Link].

Gomez, R., \& Suhaimi, A.F. (2013). Incidence rates of emotional and behavioural problems in Malaysian children as measured by parent ratings of the Strengths and Difficulties Questionnaire. Asian Journal of Psychiatry, 6(6), 528-531. [Link].

Gowdini, R., Pourmohamdreza-Tajrishi, M., Tahmasebi, S., \& Biglarian, A. (2017). Effect of Emotion Management Training to Mothers on the Behavioral Problems of Offspring: Parents' View. Jrehab, 18(1), 13-24. (Persian). [link].

Gresham, F.M., \& Elliott, S.N. (2008). Social skills improvement system rating scales manual. Minneapolis, MN: NCS Pearson. [Link].

Grossman, P., Niemann, L., Schmidt, S., \& Walach, H. (2004). Mindfulness-based stress reduction and health benefits: A meta-analysis. Journal of Psychosomatic Research, 57, 35-43. [Link].

Heslop, P., Blair, P.S., Fleming, P., Hoghton, M., Marriott, A., \& Russ, L. (2014). The Confi dential Inquiry into premature deaths of people with intellectual disabilities in the UK: a population-based study. Lancet, 383, 889-895. [Link].

Hossein Khanzadeh, A.A. (2017). Comparing the problematic social situations in students with autism and mental retardation with normal students. Journal of Psychological Science, 16(61), 124-137. (Persian). [link].

Jalil-abkenar, S.S. Ashoori, M. \& Afrooz, G.H. (2013). The Effect of Social Behaviors Training on 
Improvement of the Social Skills of Adolescents with Intellectual Disability. Journal of Rehabilitation, 14(3), 31-40. (Persian). [link].

Jones, L., Hastings, R. P., Totsika, V., Keane, L., \& Ruhle, N. (2014). Child behavior problems and parental well-being in families of children with Autism: the mediating role of mindfulness and acceptance. American Journal on Intellectual and Developmental Disabilities, 119 (2), 171-185. [Link].

Kline, R.B. (2016). Principles and practice of structural equation modeling.4th Ed. New York: Guilford. [Link].

Kolesnikova, I.S., Dolskiy, A.A., Lemskaya, N.A., Maksimova, Y.V., Shorina, A.R., Graphodatsky, A.S., Galanina, E.M., \& Yudkin, D.V. (2018). Alteration of rRNA gene copy number and expression in patients with intellectual disability and heteromorphic acrocentric chromosomes. The Egyptian Journal of Medical Human Genetics, 19, 129-134. [Link].

Langeland, E.S., \& Wahl, A.K. (2009).The impact of social support on mental health service users' sense of coherence: A longitudinal panel survey. International Journal of Nursing Studies, 46(6), 830-837. [Link].

Lima-Rodriguez, J.S., Baena-Ariza, M.T., DominguezSanchez, I., \& Lima-Serrano, M. (2018). Intellectual disability in children and teenagers: Influence on family and family health. Systematic reviewDiscapacidad intelectual en niños $y$ adolescentes: influencia en la familia y la salud familiar. Enfermeria Clinica (English Edition), 28(2), 89-102. [Link].

Magana, S. \& Ghosh, S. (2010). Latina mothers caring for a son or daughter with autism or schizophrenia: similarities, differences, and the relationship between co-residency and maternal well-being. Journal of family social work, 13(3), 227-250. [Link].

Malinauskas, R., \& Malinauskiene, V. (2018). The mediation effect of Perceived Social Support and Perceived Stress on the relationship between Emotional Intelligence and Psychological Wellbeing in Male Athletes. Journal of Human Kinetics, 31(65), 291-303. [Link].

Martins, M.V., Peterson, B.D., Almeida, V., MesquitaGuimaraes, J., \& Costa, M.E. (2014). Dyadic dynamics of perceived social support in couples facing infertility. Human Reproduction, 29(1), 839. [Link].
Matson, J.L., Esveldt-Dawson, K., \& Kazdin, A.E. (1983). Validation of methods for assessing social skills in children. Journal of Clinical Child Psychology, 12(2), 174-180. [Link].

Nejat, S., Montazeri, A., Holakouie Naieni, K., Mohammad, K., \& Majdzadeh. S. (2006), The World Health Organization quality of Life (WHOQOL-BREF) questionnaire: Translation and validation study of the Iranian version. Sjsph,4(4), 1-12. (Persian). [link].

Nikpour, M., Abedian, Z., Mokhber, N., Ebrahimzadeh, S., \& Khani, S. (2011). Comparison of Quality of Life in Women after Vaginal Delivery and Cesarean Section. Journal of Babol University of Medical Sciences, 13(1), 44-50. (Persian). [link].

Ozgur, B.G., Aksu, H., \& Eser, E. (2018). Factors affecting quality of life of caregivers of children diagnosed with autism spectrum disorder. Indian journal of psychiatry, 60(3), 278-285. [Link].

Peer, J., \& Hillman, S. (2014). Stress and Resilience for Parents of Children With Intellectual and Developmental Disabilities: A Review of Key Factors and Recommendations for Practitioners. Journal of Policy and Practice in Intellectual Disabilities, 11(2), 92-98. [Link].

Pournaghash Tehrani, S.S., Mortazavifar, S., \& Mortazavifa, S. (2020). The effect of social support and emotion regulation strategies on predicting the mental health of people with multiple sclerosis. Journal of Psychological Science, 19, (89), 529539. (Persian). [link].

Pozo, P., Sarria, E., \& Brioso, A. (2014). Family quality of life and psychological well-being in parents of children with autism spectrum disorders: a double ABCX model. Journal of Intellectual Disability Research, 58 (5), 442-458. [Link].

Ryff, C.D. (2014). Psychological well-being revisited: advances in the science and practice of eudaimonia. Psychother Psychosom, 83(1), 10-28. [Link].

Ryff, C.D. \& Singer, B.H. (2008). Know thyself and become what you are: A eudaimonic approach to psychological well-being. Journal of happiness studies, 9(1), 13-39. [Link].

Sheykholeslami, A., Taghizadeh Hir, S., Honarmand Ghojabeyglou, P., \& Moradiyan, A. (2020). Comparing the emotional well - being, marital intimacy and quality of life of mothers of children with attention deficit / hyperactivity disorder and mothers of normal children. Journal of Psychological Science, 19(87), 329-338. (Persian). [link]. 
Simms, M. (2018). Intellectual and Developmental Disability. In: Nelson Pediatric Symptom-Based Diagnosis, 367-392. [Link].

Suarez, L., Ramirez, A.G., Villarreal, R., Marti, J., Mcalister, A., Talavera, G.A., \& Perez-Stable, E.J. (2000). Social Networks and Cancer Screening in Four U.S. Hispanic groups. American Journal of Preventive Medicine, 19(1), 47-52. [Link].

Sun, J., Wang, X., Wang, Y., Du, X., \& Zhang, C. (2019). The mediating effect of perceived social support on the relationship between mindfulness and burnout in special education teachers. Journal of Community Psychology, 47(7), 1799-1809. [Link].

Tannenbaum, C., Ahmed, S., \& Mayo, N. (2007). what drives older woman's perception of health-related quality of life? Quality of life researches, 16(4), 593-605. [Link].

Teodoro, M.L., Kappler, K.C., Rodrigues, J.L., De Freitas, P.M., \& Haase, V.G. (2005). The Matson Evaluation of Social Skills with Youngsters (MESSY) and its Adaptation for Brazilian children and adolescents. International Journal of Psychology, 39 (2), 239-246. [Link].

Vega, C., Hui, F., Harman, S., Mildred, L., \& Schroeder, K. (2018). Don't Limit Me: Discussing Serious News with Intellectually Disabled Adults (FR458). Journal of Pain and Symptom Management, 55(2), 622. [Link].

Werner, S., \& Shulman, C. (2013). Subjective well-being among family caregivers of individuals with developmental disabilities: The role of affiliate stigma and psychosocial moderating variables. Research in Developmental Disabilities, 34(11), 4103-4114. [Link].

Wilson, A., Yendork, J.S., \& Somhlaba, N.Z. (2017). Psychometric Properties of Multidimensional Scale of Perceived Social Support among Ghanaian Adolescents. Child Indicators Research, 10(1), 101-115. [Link].

Winkler, L.A., Christiansen, E., Lichtenstein, M.B., Hansen, N.B., Bilenberg, N., \& Stoving, R.K. (2014). Quality of life in eating disorders: A metaanalysis. Psychiatry Research, 219 (1), 1-9. [Link].

Yousefi, F., \& Khayyer, M. (2002). Assessing the reliability and validity of the Matson Social Skills Scale and comparing the performance of high school girls and boys in this scale. Journal of Social Sciences and Humanities, Shiraz University, 18(2), 147-158. (Persian). [link]. 